\title{
OPEN Identification and selection of reference genes for gene expression analysis by quantitative real-time PCR in Suaeda glauca's response to salinity
}

\author{
Meng Wang ${ }^{1}$, Tingting Ren ${ }^{2}$, Prince Marowa ${ }^{3}$, Haina $\mathrm{Du}^{1}$ \& Zongchang $\mathrm{Xu}^{2 \bowtie}$ \\ Quantitative real-time polymerase chain reaction ( $q P C R$ ) using a stable reference gene is widely \\ used for gene expression research. Suaeda glauca $L$. is a succulent halophyte and medicinal plant \\ that is extensively used for phytoremediation and extraction of medicinal compounds. It thrives \\ under high-salt conditions, which promote the accumulation of high-value secondary metabolites. \\ However, a suitable reference gene has not been identified for gene expression standardization in \\ S. glauca under saline conditions. Here, 10 candidate reference genes, ACT7, ACT11, CCD1, TUA5, \\ UPL1, PP2A, DREB1D, V- $\mathrm{H}^{+}$-ATPase, MPK6, and PHT4;5, were selected from S. glauca transcriptome \\ data. Five statistical algorithms $(\Delta C q$, geNorm, NormFinder, BestKeeper, and RefFinder) were applied \\ to determine the expression stabilities of these genes in 72 samples at different salt concentrations \\ in different tissues. PP2A and TUA5 were the most stable reference genes in different tissues and \\ salt treatments, whereas DREB1D was the least stable. The two reference genes were sufficient \\ to normalize gene expression across all sample sets. The suitability of identified reference genes \\ was validated with $M Y B$ and $A P 2$ in germinating seeds of $S$. glauca exposed to different $\mathrm{NaCl}$ \\ concentrations. Our study provides a foundational framework for standardizing qPCR analyses, \\ enabling accurate gene expression profiling in S. glauca.
}

Suaeda glauca L. is a succulent halophyte that belongs to the Chenopodiaceae family ${ }^{1}$. It is widely distributed throughout Asia, particularly in the coastal areas of China ${ }^{2}$. Suaeda glauca is highly resistant to salt stress and thrives even in the presence of salt contents exceeding $0.48 \%$, although no salt glands or vesicles are present in the leaves ${ }^{1}$. This plant is widely used for phytoremediation of saline soils primarily because of its $\mathrm{Na}^{+}$hyperaccumulation and fast-growing properties as well as its ability to produce large amounts of biomass ${ }^{3,4}$. S. glauca also shows potential for phytoremediation of $\mathrm{Cd}, \mathrm{Pb}$, and $\mathrm{Mn}$ in contaminated soils or mine tailings ${ }^{5}$ and is used as a traditional Chinese medicinal plant to treat fever and alleviate stagnation ${ }^{6}$. The abundance of secondary metabolites makes S. glauca a multi-purpose bio-resource for both ecological and health-related issues. Particularly, the ethyl acetate-soluble fraction of the methanol extract of S. glauca is reportedly hepatoprotective ${ }^{7}$. Additionally, the anti-inflammatory, anti-mutagenic, anti-oxidative, and other bioactive properties of the flavonoid gallic acid ${ }^{8}$ lead to protective effects in the liver ${ }^{9}$. However, the content of gallic acid in S. glauca ranges between 0.62 and $0.89 \%{ }^{10}$; this low content of the active agent is the primary limitation of nearly all medicinal plants. Previous studies reported that in medicinal herbs, the contents of secondary metabolites including soluble phenolics, anthocyanins, and flavonoids were increased under salt stress ${ }^{11,12}$. Thus, salinity may be used to boost the synthesis of secondary metabolites of interest in salt-tolerant medicinal plants. However, the specific molecular regulatory mechanism is poorly understood. Furthermore, many reports have indicated that the synthesis and accumulation of plant secondary metabolites are significantly correlated with the expression level of functional genes in their biosynthesis pathways ${ }^{13,14}$. Recent research on increasing the production of active compounds in medicinal plants through recalibration and/or engineering of pivotal genes along the biosynthesis

\footnotetext{
${ }^{1}$ College of Agronomy, Qingdao Agricultural University, Qingdao, People's Republic of China. ${ }^{2}$ Marine Agriculture Research Center, Tobacco Research Institute of Chinese Academy of Agricultural Sciences, No. 11, Ke Yuan Jing 4th Road, Laoshan District, Qingdao 266101, Shandong, People's Republic of China. ${ }^{3}$ Crop Science Department, University of Zimbabwe, Harare, Zimbabwe. ${ }^{\bowtie}$ email: xuzc1110@163.com
} 
pathways has been reported ${ }^{15}$. To enable fine-tuning of these processes, gene expression levels must be gauged using appropriate technical methods.

Northern blotting, semi-quantitative reverse transcription PCR, quantitative real-time polymerase chain reaction (qPCR), and in situ hybridization are routinely used to investigate gene expression ${ }^{16}$. Among them, qPCR is highly sensitive, rapid, reproducible, specific, and safe (does not use radioactive substances) and only requires a small amount of RNA ${ }^{16-20}$. Although qPCR has been widely used to evaluate the transcription levels of mRNA, obtaining accurate and reliable results is challenging. The process of RNA extraction and quality of RNA, reverse transcription efficiency, PCR, and even sample loading are critical factors potentially undermining the reliability and reproducibility of the results ${ }^{21,22}$. To ensure the accuracy of gene expression data, endogenous genes are used as references to compare the expression levels of other genes ${ }^{18}$. The expression level of reference genes in different samples should be consistent and is unaffected by experimental conditions ${ }^{17}$. Glyceraldehyde 3-phosphate dehydrogenase (GAPDH), 18S ribosomal RNA (18S rRNA), ubiquitin-conjugating enzyme gene $(U B C), \beta$-tubulin $(\beta-T U B)$, actin $(A C T)$, $\alpha$-tubulin $(\alpha-T U B)$, clathrin adaptor complex subunit $(C A C)$, protein phosphatase 2 regulatory subunit A $(P P 2 A)$, elongation factor $1-\alpha(E F 1 \alpha)$, polyubiquitin (UBQ), SAND gene family members (SAND), TIP41-like protein gene (TIP41), cyclophilin (CYP), and DnaJ-like protein gene (DNAJ) have been applied as reference genes for expression normalization in the halophyte plants Salicornia europaea ${ }^{23}$ and S. aralocaspica ${ }^{24}$ and medicinal herbs Glycyrrhiza glabra ${ }^{25}$ and Apocynum venetum ${ }^{26}$, Actinidia chinensis ${ }^{27}$, Citrullus lanatus $^{28}$, and Arachis hypogaea ${ }^{29}$, among others. However, the reported reference genes are not commonly used in all plants, particularly under plant stress conditions ${ }^{30,31}$. The ideal reference genes for evaluating salinity stress were found to be CAC and UBC in S. europaea, whereas ACTIN and GAPDH were used for drought stress ${ }^{23}$. Additionally, to evaluate salinity stress, the ideal reference genes were shown to be $A C T B$ and $T U B B$ in Onchidium reevesii ${ }^{32}$ and TUB $\alpha$ and $18 S$ rRNA in Hibiscus cannabinus ${ }^{33}$, suggesting that the reliability of reference genes is species-specific ${ }^{34}$. Therefore, for specific plants and/or specific experimental conditions, molecular screening and identification of internal reference genes is necessary. The selection and evaluation of reference genes in S. glauca remain unreported. Thus, identifying the most suitable reference genes for S. glauca can advance further gene expression analysis protocols, which are essential methods for revealing how genes are related to the plant physiology and molecular biology.

This study was conducted to identify, select, and validate optimal reference genes in S. glauca for normalizing gene expression levels via qPCR under salinity stress. A total of 10 candidate reference genes, ACT7, ACT11, CCD1, TUA5, UPL1, PP2A, DREB1D, V-H $H^{+}$-ATPase, MPK6, and PHT4;5, were screened, and the stability of their expression in different tissues of $S$. glauca exposed to different concentrations of $\mathrm{NaCl}$ was quantified using five statistical algorithms $(\triangle \mathrm{Cq}$, geNorm, NormFinder, RefFinder and BestKeeper). Finally, the expression profiles of $M Y B$ and $A P 2$ were analyzed in germinating seeds of $S$. glauca exposed to different concentrations of $\mathrm{NaCl}$ to evaluate the usefulness of the selected reference genes.

\section{Results}

Primer specificity and amplification efficiency test of candidate reference genes. Standard PCR was used to verify the primer specificity in the amplification of all 13 candidate reference genes. Based on the results, UBC28 and TIM showed multiple bands using cDNA as the template (Supplementary File S2A), whereas EF1 $\alpha$ showed multiple bands amplified from both cDNA and genomic DNA (Supplementary File S2). These three genes were therefore discarded from further analysis. The other primers yielded a single and clear band of the expected size and there was no primer-dimer formation (Supplementary File S2). Further Sanger sequencing confirmed that the sequences of the amplified fragments were consistent with that given on NCBI, indicating the specificity of the primer pairs. The presence of a clear and single peak in melting curve analysis further verified the specificity of each primer set (Supplementary File S2). The details of the gene names, accession number, primer sequence, amplification length and efficiency, and correlation coefficient are shown in Table 1. The qPCR efficiency of all 10 candidate reference genes ranged from 87\% (MPK6) to $119 \%$ (ACT7). The determination coefficients $\left(\mathrm{R}^{2}\right)$ of the regression equation varied from 0.9763 for MPK6 to 0.9994 for UPL1.

Expression profiling of candidate reference genes in different tissues under various salinity stresses. The cycle threshold $(\mathrm{Cq})$ values generated from $\mathrm{qPCR}$ for all 10 candidate reference genes were obtained and analyzed, and their variation under each treatment is presented in Fig. 1.

The Cq values of these genes varied from 18.92 (TUA5, Fig. 1B,F) to 31.75 (DREB1D, Fig. 1A,F), suggesting that TUA5 and DREB1D were the highest and least expressed genes, respectively. Candidate reference genes in different treatments showed a somewhat similar expression pattern. However, their expression levels differed under different treatments. While selecting the ideal reference genes among different tissues, PP2A showed the highest expression level (mean Cq of 20.91), and DREB1D exhibited the lowest expression level (mean Cq of 30.67) following treatment with only 1/10 MS liquid medium (Fig. 1A). The mean Cq values for TUA5 and ACT11 were 19.20 and 27.04, and 19.12 and 26.01, for samples obtained from plants exposed to 100 and $300 \mathrm{mM} \mathrm{NaCl}$ solution, respectively (Fig. 1B,C). Interestingly, the expression levels of DREB1D and $H^{+}$-ATPase were markedly increased by $\mathrm{NaCl}$ solution treatment (Fig. 1A-C). ACT7 (mean Cq of 21.10) and TUA5 (mean Cq of 20.13) had the highest expression levels in the seed and seedling samples treated with different $\mathrm{NaCl}$ concentrations, respectively. However, DREB1D (mean Cq of 27.22) and PHT4;5 (mean Cq of 28.93) showed the lowest expression levels in the seed and seedling samples treated with different $\mathrm{NaCl}$ concentrations, respectively (Fig. 1D,E). $T U A 5, P P 2 A$, and MPK6 showed relatively high expression levels with a relatively narrow range of $\triangle \mathrm{Cq}$ of 2.94 , 3.32, and 4.00, respectively, in all samples, whereas DREB1D, $V-H^{+}$-ATPase, ACT7, and PHT4;5 showed relatively high variation with $\Delta$ Cq values of 9.73, 7.82, 7.49, and 7.25, respectively (Fig. 1F). 


\begin{tabular}{|c|c|c|c|c|c|c|c|}
\hline Accession number & Arabidopsis ortholog locus & Identity (\%) & Gene Name & Primer sequence $5^{\prime}-3^{\prime}(\mathrm{F})$ & Amplicon length & Efficiency (\%) & $\mathbf{R}^{2}$ \\
\hline \multirow{2}{*}{ BE859265.1 } & \multirow{2}{*}{ AT5G09810 } & \multirow{2}{*}{0.86} & \multirow{2}{*}{ ACT7 } & F: TAATCATCAAAATCCTGAGGA & \multirow{2}{*}{103} & \multirow{2}{*}{119} & \multirow{2}{*}{0.9972} \\
\hline & & & & R: ATTATGGTATGTAATCTTTGCGG & & & \\
\hline \multirow{2}{*}{ MF893334.1 } & \multirow{2}{*}{ AT3G12110 } & \multirow{2}{*}{0.81} & \multirow{2}{*}{ ACT11 } & F: TGTTGCTCCAGAAGAGCATC & \multirow{2}{*}{116} & \multirow{2}{*}{96} & \multirow{2}{*}{0.9969} \\
\hline & & & & R: CATACATGGCAGGGACATTG & & & \\
\hline \multirow{2}{*}{ BF114443.1 } & \multirow{2}{*}{ AT3G63520 } & \multirow{2}{*}{0.85} & \multirow{2}{*}{ CCD1 } & F: CCCAATCAAGGGTTCACTTC & \multirow{2}{*}{108} & \multirow{2}{*}{107} & \multirow{2}{*}{0.9988} \\
\hline & & & & R: GTGTTGAGGTTGTGAAGAATCA & & & \\
\hline \multirow{2}{*}{ AW990992.1 } & \multirow{2}{*}{ AT5G19780 } & \multirow{2}{*}{0.86} & \multirow{2}{*}{ TUA5 } & F: GGCACAATGCACTAAGCAAC & \multirow{2}{*}{110} & \multirow{2}{*}{98} & \multirow{2}{*}{0.9991} \\
\hline & & & & R: AAGGTGCCGAGGATGATGAT & & & \\
\hline \multirow{2}{*}{ BE240972.1 } & AT1G55860 & 0.84 & UPL1 & F: GAGTGGTACCAGCTATTGTC & 103 & 114 & 0.9994 _ \\
\hline & AllG55860 & 0.84 & UPLI & R: AGACAGAATTAGGGTTTGGCT & 103 & 114 & 0.9994 \\
\hline BE8592001 & AT1G64230 & 081 & UBC28 & F: CCCTCCAGATTATCCATTTAAG & 106 & - & _ \\
\hline DEOSYZU.1 & A1 1004250 & 0.01 & ODCZO & R: CTCCTTTAGGATGTCAAGACA & 100 & $\left.\right|^{-}$ & $\left.\right|^{-}$ \\
\hline BE644594] & AT5G60390 & 0.91 & $\mathrm{FF} 1 \mathrm{a}$ & F: AGACCAACAAGTACTACTGCA & 108 & - & - \\
\hline ВЕ644594.1 & Al5G60390 & 0.91 & EFla & R: CAATAATAAGGATAGCGCAGTC & 108 & - & - \\
\hline & & & & F: CTTAGTATTCCСATTTCTTCATCT & & & \\
\hline BE240909.1 & AT1G69960 & 0.78 & PP2A & R: ATGAGGACACAAAAAGAGCCAT & 144 & 104 & 0.9975 \\
\hline KM679415 1 & AT5G51990 & 071 & DREB1D & F: CGACAGACACTAGGGAAATTC & 107 & 95 & 09923 \\
\hline N1VIO/9415.1 & A15 & 0.11 & DKEDID & R: GTCATTCATGCTGCTATTCTC & 107 & 90 & 0.9923 \\
\hline BF2313851 & АТТ & 077 & TIM & F: GTTGTTACTATGGCTGGCTC & 111 & $C_{-}$ & $L_{-}$ \\
\hline БЕ201385.1 & A12G $211 / 0$ & 0.77 & $11 \mathrm{M}$ & R: CAATGTTGCACTGTTCAAGTCT & 111 & $\left.\right|^{-}$ & $\left.\right|^{-}$ \\
\hline BF1450831 & AT3G42050 & 077 & V-H-_-ATPase & F: CTAGCATAATTTCTGCAAAGCC & 119 & 107 & 0994 \\
\hline DF14508.1 & A1 0044050 & 0.11 & V-TIt-AIPase & R: CTGTTCCAGTGATCAACTTAGT & 119 & 107 & 0.994 \\
\hline BE6567161 & At2043790 & 081 & MPK6 & F: CAACCTCATTCATCAGTCATCA & 112 & 87 & 09763 \\
\hline ВЕ656/16.1 & At $2943 / 90$ & 0.81 & MIPKo & R: TGGTTTGCGGTGGTTGATTAG & 112 & 87 & 0.9763 \\
\hline & & & & F: AGCAACAGCATTCGTTCCAG & & & \\
\hline AW982148.1 & AT5G20380 & 0.75 & PHT4;5 & R: GATCTGTGGCAGCTGATGGT & 106 & 106 & 0.9983 \\
\hline & & & & R: AACTTCAAAGGCAATGTTGAAAAC & & & \\
\hline BE644575] & At 5052660 & 085 & MYB & F: CTGCTAATGTGGTGTCACCAT & 114 & 98 & 09923 \\
\hline BE644575.1 & At5g52660 & 0.85 & MYB & R: CATGCTCTTCTTCAGTCCAAC & 114 & 98 & 0.9923 \\
\hline BF2313711 & $L_{-}$ & _ & AP2 & F: ААСТCTТTCTTCСТTAАТСАСТCT & 124 & 95 & 09748 \\
\hline DE $2313 / 1.1$ & $\left.\right|^{-}$ & $\left.\right|^{-}$ & APL & R: CGTCGATAAAGTTCTCATTTTTAC & 124 & 90 & $0.9 / 48$ - \\
\hline
\end{tabular}

Table 1. Primer sequences and amplification characteristics of candidate reference genes of $S$. glauca used in this study. Amplicon length was obtained using cDNA as a template.

Stability assessment of candidate reference genes. Four specialized analytical tools, geNorm, NormFinder, BestKeeper, and RefFinder, were used to further assess the stability of the candidate reference genes in different responses of $S$. glauca tissues to salinity stress.

geNorm analysis. In geNorm analysis, a lower $\mathrm{M}$ value indicates more stable gene expression and vice versa. All $\mathrm{M}$ values of the 10 candidate reference genes in each treatment were lower than 0.7 (Fig. 2), which is much lower than the default limit of 1.5, indicating high expression stability. However, for tissue experiments, the three most stable genes were TUA5, PP2A, and MPK6 with the lowest $M$ values, whereas DREB1D was the most unstable gene (Fig. 2A-C). In the seed group, TUA5 and $P P 2 A$ were the two most stable genes at all different concentrations of $\mathrm{NaCl}$ treatments (Fig. 2D). In the seedlings group, $P P 2 A$ and $M P K 6$ were the most stable genes, followed by $V-H+-A T P a s e$, whereas $A C T 7$ and DREB1D were the least stable genes (Fig. 2E). Finally, for all sample sets, TUA5 and PP2A showed the lowest $M$ value, and $A C T 7$ was the most unstable gene (Fig. $2 \mathrm{~F}$ ). To determine the optimal number of reference genes required for accurate experimental normalization, pairwise variations of the normalization factor $\left(\mathrm{V}_{\mathrm{n}} / \mathrm{V}_{\mathrm{n}+1}\right)$ were analyzed using geNorm. The $\mathrm{V}_{2} / \mathrm{s}_{3}$ values of all different experimental groups were below the threshold value of 0.15 , indicating that two reference genes are sufficient to normalize gene expression data (Fig. 3).

NormFinder analysis. NormFinder, which is an analysis program based on the variation estimation statistical approach, was used to evaluate the expression stability of the candidate reference genes. A lower average expression stability indicates more stable gene expression. The stability values of the candidate reference genes in each treatment are listed in Table 2. For tissues experiment under 1/10 MS liquid medium, $P P 2 A$ and TUA5 were the most stable reference genes and DREB1D was the least stable gene, which agreed with the results of geNorm analysis. For tissues experiment under $100 \mathrm{mM} \mathrm{NaCl}, M P K 6$ and $P P 2 A$ were the most stable reference genes, whereas ACT11 was the least stable gene. Similarly, the most sta- 

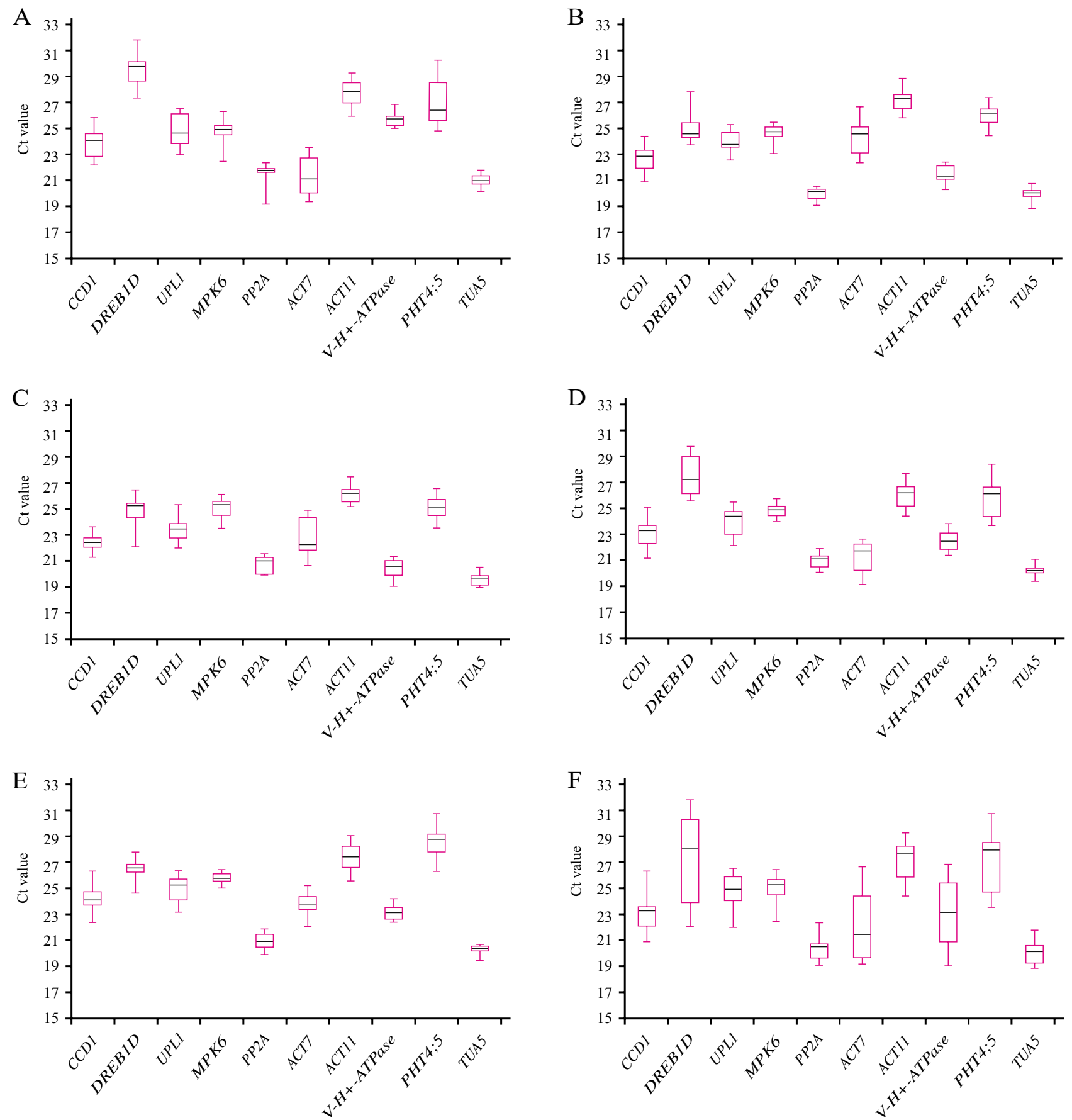

Figure 1. Boxplots showing the expression patterns of candidate reference genes of S. glauca represented by raw Cq values. The box indicates the 25 th and 75 th percentiles, and whisker caps represent the maximum and minimum values. The black line across the box depicts the median. (A) Thirteen tissue samples derived from 1/10 MS liquid medium treatment. (B) Thirteen tissue samples derived from $100 \mathrm{mM} \mathrm{NaCl}$ treatment. (C) Thirteen tissue samples derived from $300 \mathrm{mM} \mathrm{NaCl}$ treatment. (D) Fifteen germinating seed samples derived from $\mathrm{NaCl}$ gradient treatment. (E) Eighteen seedling samples derived from $\mathrm{NaCl}$ gradient treatment. (F) All 72 samples used in this study.

ble reference genes identified in tissue experiments under $300 \mathrm{mM} \mathrm{NaCl}$ were TUA5 and PP2A, whereas $P H T 4 ; 5$ was the least stable gene. The order of reference gene stability in seeds under $\mathrm{NaCl}$ treatments was: $M P K 6>P P 2 A>T U A 5>V-H^{+}$-ATPase $>U P L 1>C C D 1>A C T 11>A C T 7>P H T 4 ; 5>D R E B 1 D$. The ranking of gene stability across seedlings under $\mathrm{NaCl}$ treatment was: $P P 2 A>M P K 6>$ TUA5 $>A C T 11>C C D 1>V-H^{+}-$ ATPase $>$ PHT4;5 $>A C T 7>U P L 1>D R E B 1 D$. In all samples, TUA5, PP2A, and MPK6 were the most stable reference genes and DREB1D and PHT4;5 were the least ranked reference genes, which agrees with the results of geNorm analysis. 
A

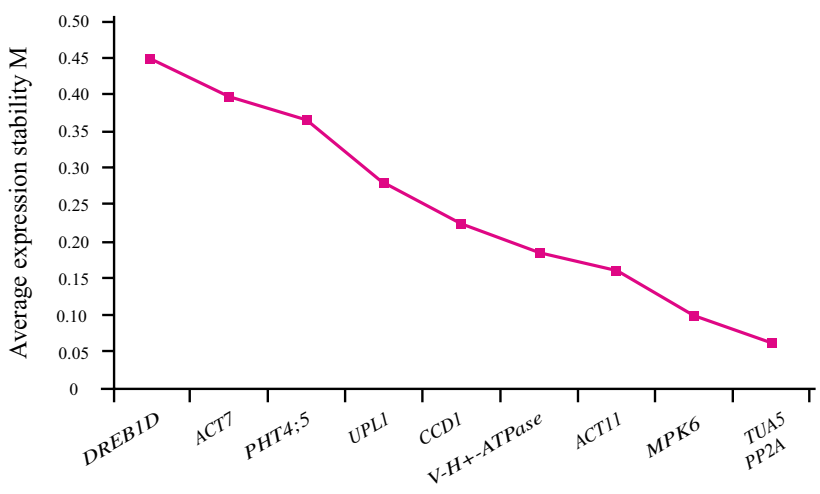

$\xi==$ Least stable genes - Most stable genes $==-\Rightarrow$

$\mathrm{C}$

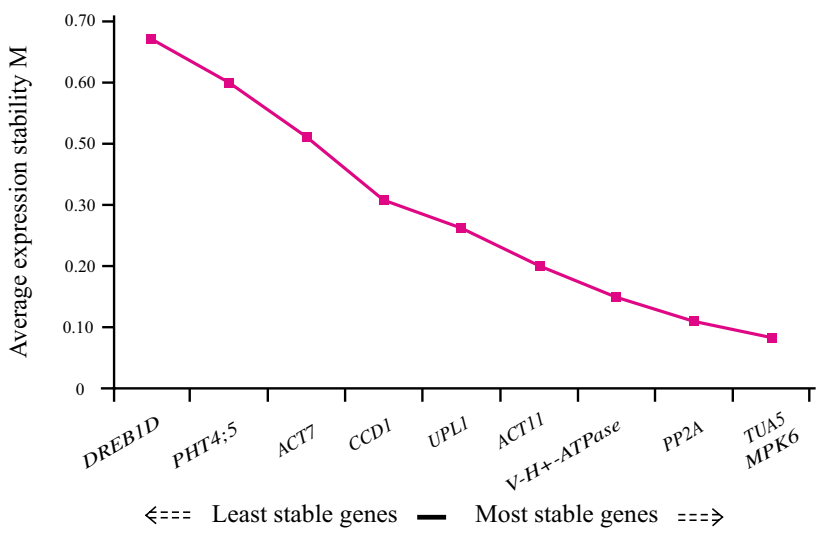

$\mathrm{E}$

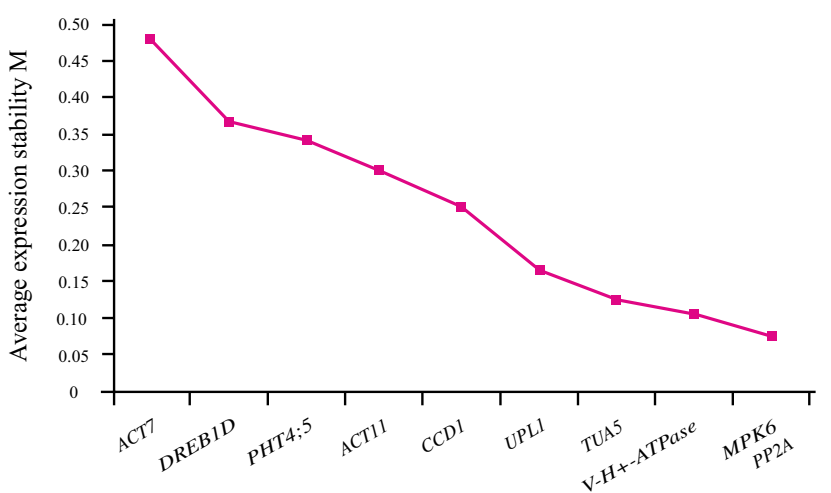

$\varepsilon===$ Least stable genes - Most stable genes $===\Rightarrow$
B

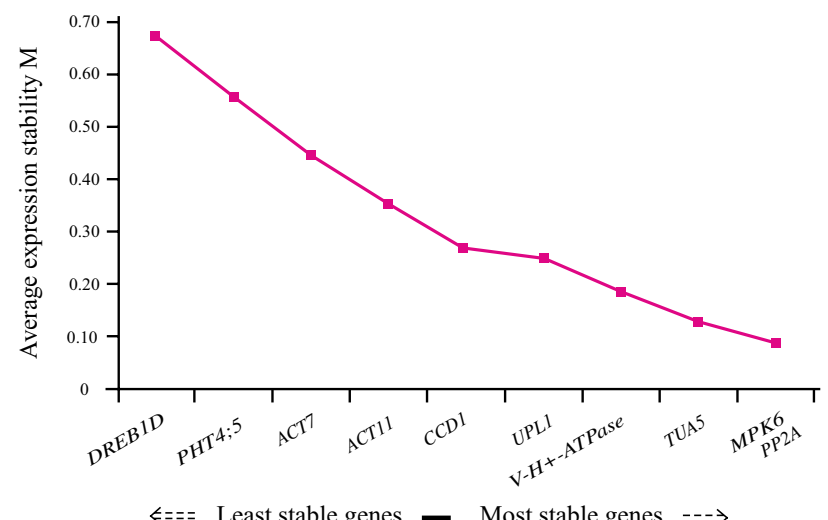

$\mathrm{D}$

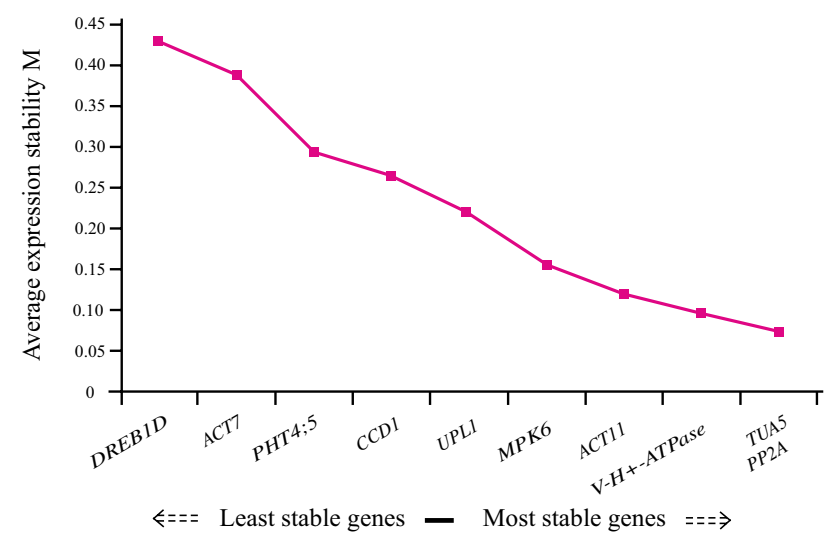

$\mathrm{F}$

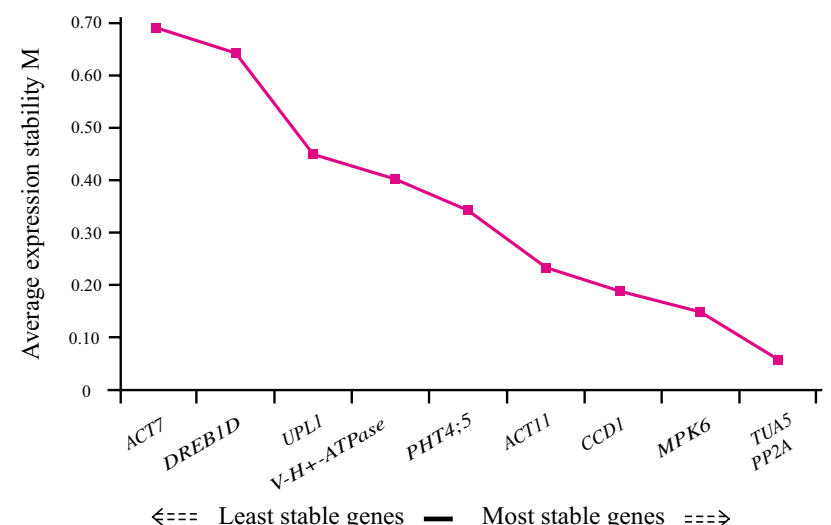

Figure 2. Gene expression stability values $(M)$ of ten candidate reference genes validated via geNorm program. The least stable genes are on the left with higher $M$-values, and the most stable genes are on the right with lower $M$-values. (A) Thirteen tissue samples derived from 1/10 MS liquid medium treatment. (B) Thirteen tissue samples derived from $100 \mathrm{mM} \mathrm{NaCl}$ treatment. (C) Thirteen tissue samples derived from $300 \mathrm{mM} \mathrm{NaCl}$ treatment. (D) Fifteen germinating seed samples derived from $\mathrm{NaCl}$ gradient treatment. (E) Eighteen seedling samples derived from $\mathrm{NaCl}$ gradient treatment. (F) All 72 samples used in this study.

BestKeeper analysis. The SD and $r$ value of candidate reference genes in each treatment are listed in Table 3. Similar to the results of geNorm and NormFinder analysis, the three most stable genes were $M P K 6, P P 2 A$, and TUA5, whereas DREB1D was the least stable gene in tissues (1/10 MS liquid medium). In addition to PP2A, TUA5, and MPK6, $V-H^{+}$-ATPase was regarded as relatively stable in tissue experiments, both in 100 and $300 \mathrm{mM}$ $\mathrm{NaCl}$ treatments. However, the two least stable genes in tissues after $100 \mathrm{mM} \mathrm{NaCl}$ treatment were DREB1D and ACT7. DREB1D and PHT4;5 were the two least stable genes in $300 \mathrm{mM} \mathrm{NaCl}$-treated tissues. For seed and seedling experiments, the top three most stable genes were again PP2A, TUA5, and MPK6, whereas DREB1D was the least stable gene for the two experiments. Overall, in the total samples, similar to the geNorm and NormFinder 


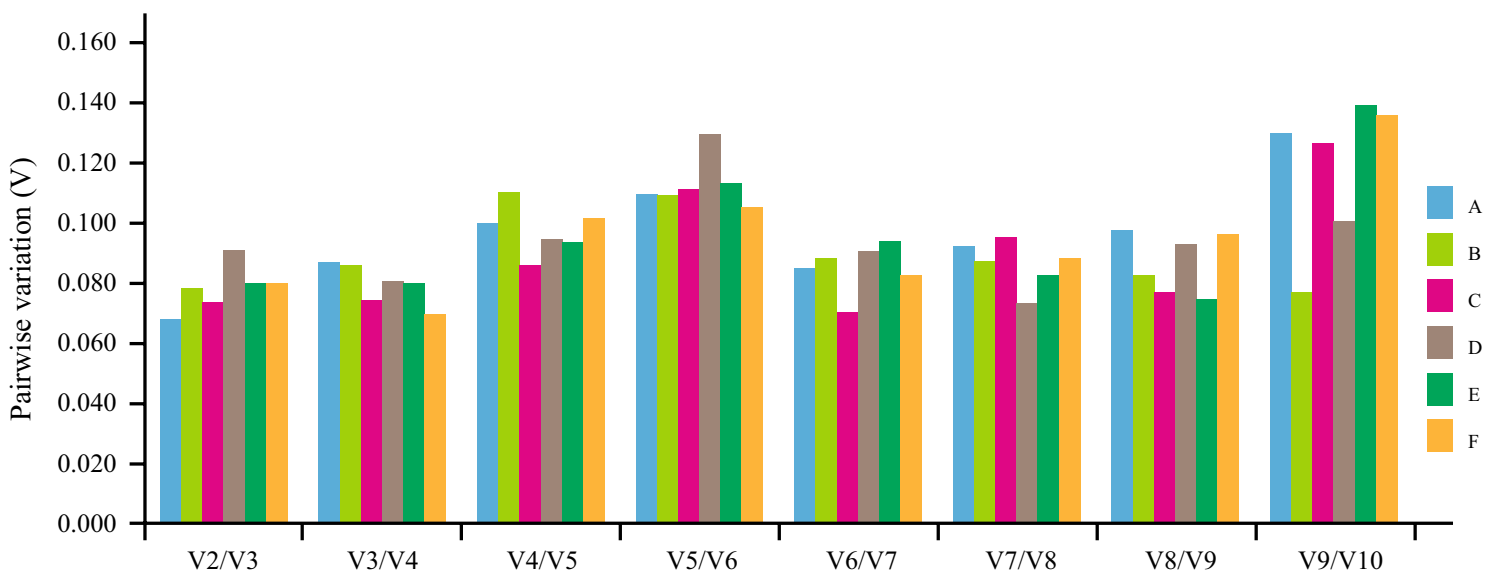

\begin{tabular}{|c|c|c|c|c|c|c|c|c|}
\hline & $\mathrm{v} 2 / \mathrm{v} 3$ & $\mathrm{v} 3 / \mathrm{v} 4$ & $\mathrm{v} 4 / \mathrm{v} 5$ & $\mathrm{v} 5 / \mathrm{v} 6$ & $\mathrm{v} 6 / \mathrm{v} 7$ & $\mathrm{v} 7 / \mathrm{v} 8$ & $\mathrm{v} 8 / \mathrm{v} 9$ & $\mathrm{v} 9 / \mathrm{v} 10$ \\
\hline $\mathrm{A}$ & 0.0681 & 0.0867 & 0.0995 & 0.1096 & 0.0848 & 0.0922 & 0.0977 & 0.1293 \\
\hline $\mathrm{B}$ & 0.0782 & 0.0857 & 0.1104 & 0.1093 & 0.0883 & 0.0867 & 0.0827 & 0.0772 \\
\hline $\mathrm{C}$ & 0.0732 & 0.0741 & 0.0852 & 0.1111 & 0.0702 & 0.0959 & 0.0766 & 0.1268 \\
\hline $\mathrm{D}$ & 0.0909 & 0.0795 & 0.0941 & 0.1296 & 0.0903 & 0.0733 & 0.0928 & 0.1002 \\
\hline $\mathrm{E}$ & 0.0793 & 0.0800 & 0.0935 & 0.1131 & 0.0935 & 0.0819 & 0.0750 & 0.1389 \\
\hline F & 0.0798 & 0.0694 & 0.1016 & 0.1053 & 0.0818 & 0.0883 & 0.0964 & 0.1361 \\
\hline
\end{tabular}

Figure 3. Optimal number of reference genes in different experimental groups calculated using geNorm. Pairwise variation $\left(\mathrm{V}_{\mathrm{n}} / \mathrm{V}_{\mathrm{n}+1}\right)$ analysis of 10 candidate reference genes analyzed in six sample subsets. (A) Thirteen tissue samples derived from 1/10 MS liquid medium treatment. (B) Thirteen tissue samples derived from $100 \mathrm{mM} \mathrm{NaCl}$ treatment. (C) Thirteen tissue samples derived from $300 \mathrm{mM} \mathrm{NaCl}$ treatment. (D) Fifteen germinating seed samples derived from $\mathrm{NaCl}$ gradient treatment. (E) Eighteen seedling samples derived from $\mathrm{NaCl}$ gradient treatment. (F) All 72 samples used in this study.

\begin{tabular}{|c|c|c|c|c|c|c|c|c|c|c|c|c|}
\hline \multirow[b]{2}{*}{ Order } & \multicolumn{2}{|l|}{ A } & \multicolumn{2}{|l|}{ B } & \multicolumn{2}{|l|}{$\mathrm{C}$} & \multicolumn{2}{|l|}{ D } & \multicolumn{2}{|l|}{$\mathrm{E}$} & \multicolumn{2}{|l|}{ F } \\
\hline & Gene & Stability & Gene & Stability & Gene & Stability & Gene & Stability & Gene & Stability & Gene & Stability \\
\hline 1 & $P P 2 A$ & 0.059 & MPK6 & 0.152 & TUA5 & 0.127 & MPK6 & 0.092 & $P P 2 A$ & 0.124 & TUA5 & 0.069 \\
\hline 2 & TUA5 & 0.1 & $P P 2 A$ & 0.153 & $P P 2 A$ & 0.127 & $P P 2 A$ & 0.106 & MPК6 & 0.138 & $P P 2 A$ & 0.113 \\
\hline 3 & MPК6 & 0.124 & TUA5 & 0.168 & MPK6 & 0.157 & TUA5 & 0.126 & TUA5 & 0.143 & MPK6 & 0.143 \\
\hline 4 & CCD1 & 0.132 & $U P L 1$ & 0.189 & $V$ - $H^{+}$-ATPase & 0.173 & $V$ - $H^{+}$-ATPase & 0.200 & ACT11 & 0.161 & ACT7 & 0.192 \\
\hline 5 & $U P L 1$ & 0.147 & CCD1 & 0.207 & ACT11 & 0.183 & UPL1 & 0.205 & CCD1 & 0.206 & V-H $H^{+}$-ATPase & 0.209 \\
\hline 6 & V-H $H^{+}$-ATPase & 0.153 & V-H $H^{+}$-ATPase & 0.217 & CCD1 & 0.185 & CCD1 & 0.206 & V-H $H^{+}$-ATPase & 0.219 & CCD1 & 0.227 \\
\hline 7 & ACT11 & 0.189 & PHT4;5 & 0.252 & UPL1 & 0.241 & ACT11 & 0.218 & PHT4;5 & 0.265 & UPL1 & 0.230 \\
\hline 8 & ACT7 & 0.261 & ACT7 & 0.271 & ACT7 & 0.306 & ACT7 & 0.304 & ACT7 & 0.279 & DREB1D & 0.302 \\
\hline 9 & PHT4;5 & 0.301 & DREB1D & 0.372 & DREB1D & 0.356 & PHT4;5 & 0.368 & UPL1 & 0.302 & ACT11 & 0.317 \\
\hline 10 & DREB1D & 0.346 & ACT11 & 0.394 & PHT4;5 & 0.408 & $D R E B 1 D$ & 0.394 & DREB1D & 0.440 & PHT4;5 & 0.353 \\
\hline
\end{tabular}

Table 2. Stability assessment of all candidate reference genes of $S$. glauca plants' response to salinity stresses calculated using the NormFinder algorithms. A: Thirteen tissue samples derived from 1/10 MS liquid medium treatment. B: Thirteen tissue samples derived from $100 \mathrm{mM} \mathrm{NaCl}$ treatment. C: Thirteen tissue samples derived from $300 \mathrm{mM} \mathrm{NaCl}$ treatment. D: Fifteen germinating seed samples derived from $\mathrm{NaCl}$ gradient treatment. E: Eighteen seedling samples derived from $\mathrm{NaCl}$ gradient treatment. F: All 72 samples used in this study.

analyses, BestKeeper showed that TUA5, PP2A, and MPK6 were the most stable genes and PHT4;5 and DREB1D were the least stable genes.

RefFinder analysis. The comprehensive rankings of the candidate reference genes were ordered by the weighted geometric mean obtained by the RefFinder algorithm, which was based on the results of standard analysis programs (geNorm, NormFinder, BestKeeper). PP2A displayed the highest stability among all treatment samples, consistently ranking at the top in all subsets [tissues treated with $1 / 10 \mathrm{MS}$ liquid medium, $100 \mathrm{mM} \mathrm{NaCl}$, and $300 \mathrm{mM} \mathrm{NaCl}$; germinating seeds under different $\mathrm{NaCl}$ concentrations; seedlings under different $\mathrm{NaCl}$ concentrations; and all samples] (Fig. 4). TUA5 was the second-most stable gene, which consistently ranked in second place, in four experiments (tissues (1/10 MS liquid medium), tissues $(300 \mathrm{mM} \mathrm{NaCl})$, germinating seeds $(\mathrm{NaCl}$ 


\begin{tabular}{|c|c|c|c|c|c|c|c|c|c|c|c|c|c|c|c|c|c|c|}
\hline \multirow[b]{2}{*}{ Order } & \multicolumn{3}{|l|}{$\mathbf{A}$} & \multicolumn{3}{|l|}{ B } & \multicolumn{3}{|l|}{$\mathrm{C}$} & \multicolumn{3}{|l|}{ D } & \multicolumn{3}{|l|}{ E } & \multicolumn{3}{|l|}{ F } \\
\hline & Gene & SD & \begin{tabular}{|l|} 
coeff. \\
of corr. \\
{$[r]$}
\end{tabular} & Gene & SD & \begin{tabular}{|l} 
coeff. \\
of corr. \\
{$[r]$}
\end{tabular} & Gene & SD & \begin{tabular}{|l|} 
coeff. \\
of corr. \\
{$[r]$}
\end{tabular} & Gene & SD & \begin{tabular}{|l|} 
coeff. \\
of corr. \\
{$[r]$}
\end{tabular} & Gene & SD & $\begin{array}{l}\text { coeff. } \\
\text { of corr. } \\
{[r]}\end{array}$ & Gene & SD & \begin{tabular}{|l|} 
coeff. \\
of corr. \\
{$[r]$}
\end{tabular} \\
\hline 1 & MPK6 & 0.49 & \begin{tabular}{|l|l}
0.998 \\
\end{tabular} & $P P 2 A$ & 0.53 & 0.998 & TUA5 & 0.50 & \begin{tabular}{|l|}
0.999 \\
\end{tabular} & PP2A & 0.53 & 0.999 & TUA5 & 0.50 & 0.999 & MPK6 & 0.58 & 0.999 \\
\hline 2 & PP2A & 0.41 & 0.978 & $\begin{array}{l}\text { V-H } H^{+}- \\
\text {ATPase }\end{array}$ & 0.48 & 0.983 & PP2A & 0.44 & 0.980 & MPК6 & 0.51 & 0.979 & PP2A & 0.50 & 0.979 & $P P 2 A$ & 0.50 & 0.982 \\
\hline 3 & TUA5 & 0.45 & 0.971 & TUA5 & 0.53 & 0.971 & $\begin{array}{l}\text { V-H } H^{+}- \\
\text {ATPase }\end{array}$ & 0.51 & 0.971 & TUA5 & 0.48 & 0.978 & МРК6 & 0.56 & 0.977 & TUA5 & 0.53 & 0.979 \\
\hline 4 & CCD1 & 0.22 & 0.964 & MPK6 & 0.30 & 0.966 & MPK6 & 0.33 & 0.971 & $\begin{array}{l}\text { V-H } H^{+}- \\
\text {ATPase }\end{array}$ & 0.27 & 0.972 & $\begin{array}{l}\text { V-H+ } H^{+} \\
\text {ATPase }\end{array}$ & 0.29 & 0.969 & UPL1 & 0.23 & 0.970 \\
\hline 5 & $\begin{array}{l}\text { V-H+ } H^{+} \\
\text {ATPase }\end{array}$ & 0.38 & 0.961 & ACT11 & 0.44 & 0.949 & $C C D 1$ & 0.46 & 0.966 & UPL1 & 0.42 & 0.955 & ACT11 & 0.46 & 0.967 & ACT11 & 0.47 & 0.962 \\
\hline 6 & ACT11 & 0.52 & 0.881 & $C C D 1$ & 0.61 & 0.826 & ACT11 & 0.60 & 0.874 & ACT11 & 0.54 & 0.883 & UPL1 & 0.54 & 0.839 & ACT7 & 0.61 & 0.847 \\
\hline 7 & UPL1 & 0.30 & 0.76 & UPL1 & 0.33 & 0.774 & UPL1 & 0.41 & 0.729 & CCD1 & 0.33 & \begin{tabular}{|l|}
0.777 \\
\end{tabular} & CCD1 & 0.31 & 0.756 & CCD1 & 0.35 & 0.774 \\
\hline 8 & PHT4;5 & 0.53 & 0.718 & PHT4;5 & 0.54 & 0.719 & ACT7 & 0.64 & 0.723 & PHT4;5 & 0.65 & 0.726 & DREB1D & 0.64 & 0.722 & PHT4;5 & 0.63 & 0.627 \\
\hline 9 & ACT7 & 0.40 & 0.471 & $A C T 7$ & 0.49 & 0.472 & PHT $4 ; 5$ & 0.46 & 0.472 & DREBID & 0.49 & 0.380 & ACT7 & 0.49 & 0.278 & \begin{tabular}{|l|l|}
$V-H^{+}-$ \\
ATPase
\end{tabular} & 0.43 & 0.472 \\
\hline 10 & DREB1D & 0.28 & 0.083 & DREB1D & 0.30 & 0.187 & DREB1D & 0.40 & 0.289 & ACT7 & 0.40 & 0.088 & PHT4;5 & 0.28 & 0.085 & DREB1D & 0.36 & 0.193 \\
\hline
\end{tabular}

Table 3. Stability assessment of all candidate reference genes of S. glauca plants' response to salinity stresses calculated using the BestKeeper algorithms. A: Thirteen tissue samples derived from 1/10 MS liquid medium treatment. B: Thirteen tissue samples derived from $100 \mathrm{mM} \mathrm{NaCl}$ treatment. C: Thirteen tissue samples derived from $300 \mathrm{mM} \mathrm{NaCl}$ treatment. D: Fifteen germinating seed samples derived from $\mathrm{NaCl}$ gradient treatment. E: Eighteen seedling samples derived from $\mathrm{NaCl}$ gradient treatment. F: All 72 samples used in this study.

gradient), and all samples) and third in two experiments (tissues $(100 \mathrm{mM} \mathrm{NaCl})$, and seedlings $(\mathrm{NaCl}$ gradient)) (Fig. 4). MPK6 was followed by TUA5, consistently ranking third. However, the order of the least stable genes among all treatment samples was DREB1D>ACT7>PHT4;5 (Fig. 4).

Validation of identified stable reference genes. To validate the suitability of the two selected reference genes, $P P 2 A$ and TUA5, and the least stable reference gene DREB1D, the salt-induced expression level of $M Y B$ and $A P 2$ in germinating seeds was normalized via qPCR. $M Y B$ (Fig. 5A) and AP2 (Fig. 5B) showed similar expression levels when a single or a combination of reference genes ( $P P 2 A$ and TUA5) was used to normalize the expression. The expression levels of $M Y B$ and $A P 2$ were upregulated in all seed samples treated with different concentrations of $\mathrm{NaCl}$. However, when $D R E B 1 D$ (unstable gene) was used for normalization, the relative expression patterns of $M Y B$ and $A P 2$ differed as compared to the relative expression values obtained using the two most stable reference genes ( $P P 2 A$ and TUA5) (Fig. 5), highlighting the significance of selecting appropriate internal reference genes under salt stress.

\section{Discussion}

Gene expression analysis is a primary method for revealing the mechanism of plants' responses to different conditions, including abiotic stresses ${ }^{23}$. qPCR is an efficient and reliable method for assessing gene expression levels. However, the accuracy of the results is affected by the expression level and stability of internal reference genes. Using inappropriate reference genes can lead to misleading results ${ }^{42}$. Hence, application of steadily expressed internal reference genes is key to obtaining accurate results ${ }^{20,43}$. Commonly used methods for selecting candidate internal reference genes include searching the literature or using housekeeping genes, such as genes involved in cell metabolism, glycolysis, protein degradation, and synthesis ${ }^{44}$. However, previous studies reported that the expression level of internal reference genes obtained by this method may be unstable under different experimental conditions ${ }^{45}$, greatly affecting the accuracy of the results. Compared with the validated reference genes, the expression level of target genes can show 100-fold deviation using inadequately validated reference genes. Thus, using reference genes obtained by traditional methods may lead to erroneous or even contradictory results ${ }^{21,43}$. Therefore, constant expression in different tissues or experimental treatments is a vital feature of an ideal reference gene ${ }^{46}$. Generally, candidate reference genes belong to different types of functional genes, which can significantly reduce the risk of gene expression being affected. S. glauca, a succulent halophyte ${ }^{1}$, is used as a traditional Chinese medicinal herb because of its health-promoting pharmacodynamic effects ${ }^{6}$. In a previous study, ACTIN was used as the reference gene to normalize the salt response gene under salt stress ${ }^{2}$. Similarly, EF1 $\alpha$ was used as a reference gene in another Suaeda species ( $S$. salsa) to normalize the gene expression level under salt stress ${ }^{47}$. However, there are no reports on the systematic screening and identification of internal reference genes of $S$. glauca under salt stress. In this study, after a series of systematic screening steps, 10 reference genes were selected for further screening and validation as potential gene expression normalization genes under salt stress in S. glauca. Further assessment with $\triangle \mathrm{Cq}$, geNorm, NormFinder, BestKeeper, and RefFinder software identified PP2A and TUA5 as the two most stable reference genes, whereas DREB1D was the most unstable gene in all samples. Notably, these reference genes belong to different functional gene classes. A previous study reported that $G A P D H, A C T B$, and $18 \mathrm{~S}$ and $28 \mathrm{~S}$ rRNA were the most frequently used reference 

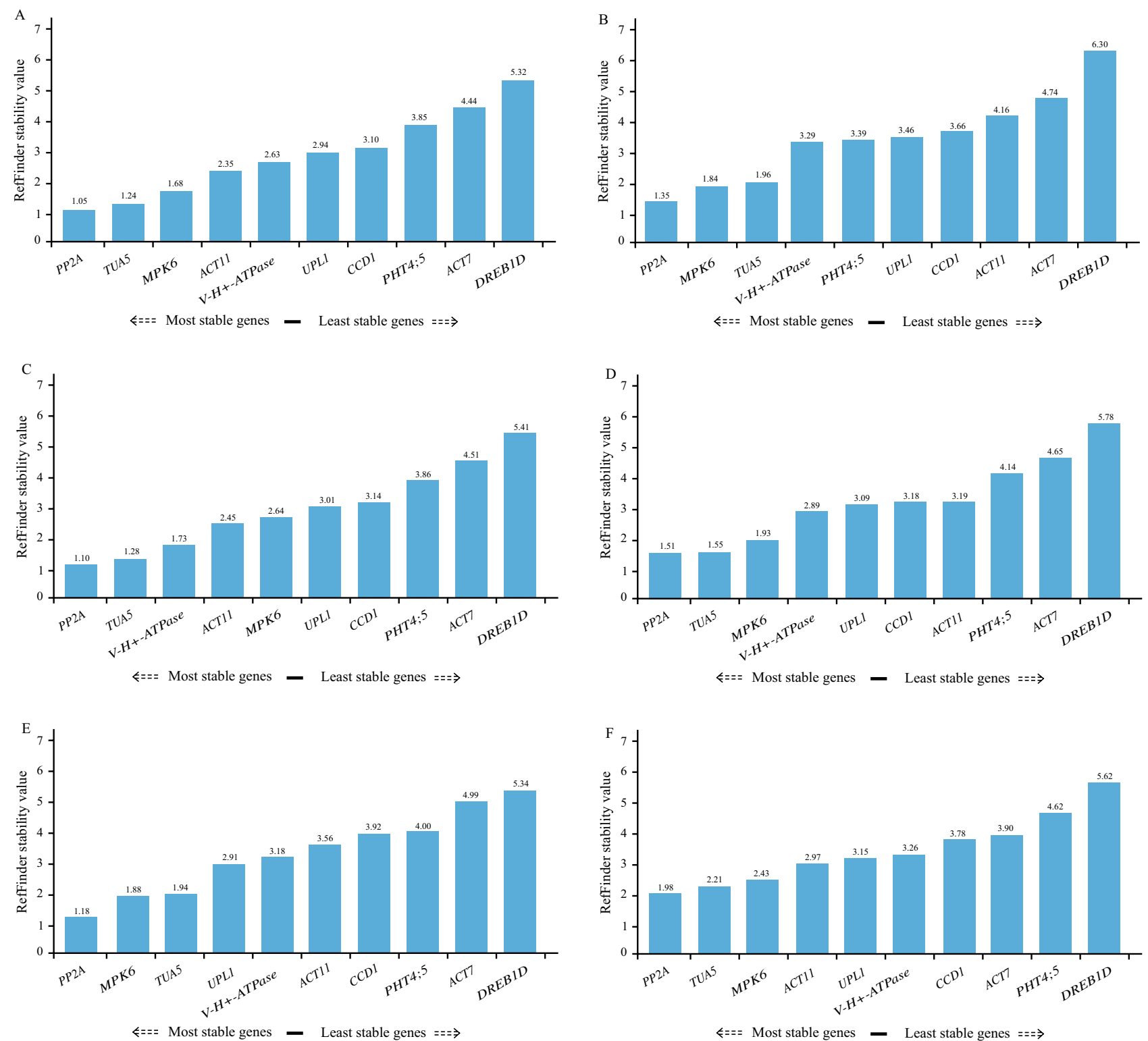

Figure 4. Expression stability of candidate genes in different tissues of $S$. glauca response to salinity validated by RefFinder program. (A) Thirteen tissue samples derived from 1/10 MS liquid medium treatment. (B) Thirteen tissue samples derived from $100 \mathrm{mM} \mathrm{NaCl}$ treatment. (C) Thirteen tissue samples derived from $300 \mathrm{mM} \mathrm{NaCl}$ treatment. (D) Fifteen germinating seed samples derived from $\mathrm{NaCl}$ gradient treatment. (E) Eighteen seedling samples derived from $\mathrm{NaCl}$ gradient treatment. (F) All 72 samples used in this study.

genes in articles published by high-impact journals (more than $90 \%$ cases) ${ }^{48}$. However, in this study, none of these genes were identified as suitable reference genes for S. glauca. GAPDH was reported as the most appropriate reference gene under different salinity stress conditions for S. aralocaspica, which belongs to the same genus as S. glauca $^{24}$. The constitutively expressed, housekeeping enzyme GAPDH converts glyceraldehyde-3-phosphate into 1,3-bisphosphoglycerate, which plays a key role in glycolysis. Hence, GAPDH is widely used as a reference gene ${ }^{49}$. Additionally, $A v G A P D H-2$ has been identified as the most stable reference gene in another traditional Chinese herb, A. venetum, under salinity stress ${ }^{26}$. Previous studies reported that GAPDH was one of the best reference genes in different tissue and organ samples of teak ${ }^{50}$ and Dendrocalamus latiflorus ${ }^{34}$ because of its high stable expression. However, GAPDH was not a suitable reference gene in rice under water-deficient conditions because of the high expression instability ${ }^{51}$. These results indicate that reference genes effective in one species may not be appliable in other species ${ }^{34}$. Although orthologous genes of DREB1D, PHT4;5, and ACT7 have been effectively used in studies of Fagopyrum tataricum ${ }^{52}$, A. hypogaea ${ }^{29}$, and A. venetum ${ }^{26}$, our comprehensive analysis showed that these were the top three most unstable genes in S. glauca. In contrast, PP2A and TUA5 were identified as the two most stable reference genes in the response of $S$. glauca to salinity. These genes were also chosen as optimal reference genes in C. lanatus ${ }^{28}$, A. hypogaea ${ }^{29}$, Heterosigma akashiwo ${ }^{53}$ and Eucalyptus ${ }^{54}$. In fact, many studies selected a series of reference genes that have been reported in other plants and screened 

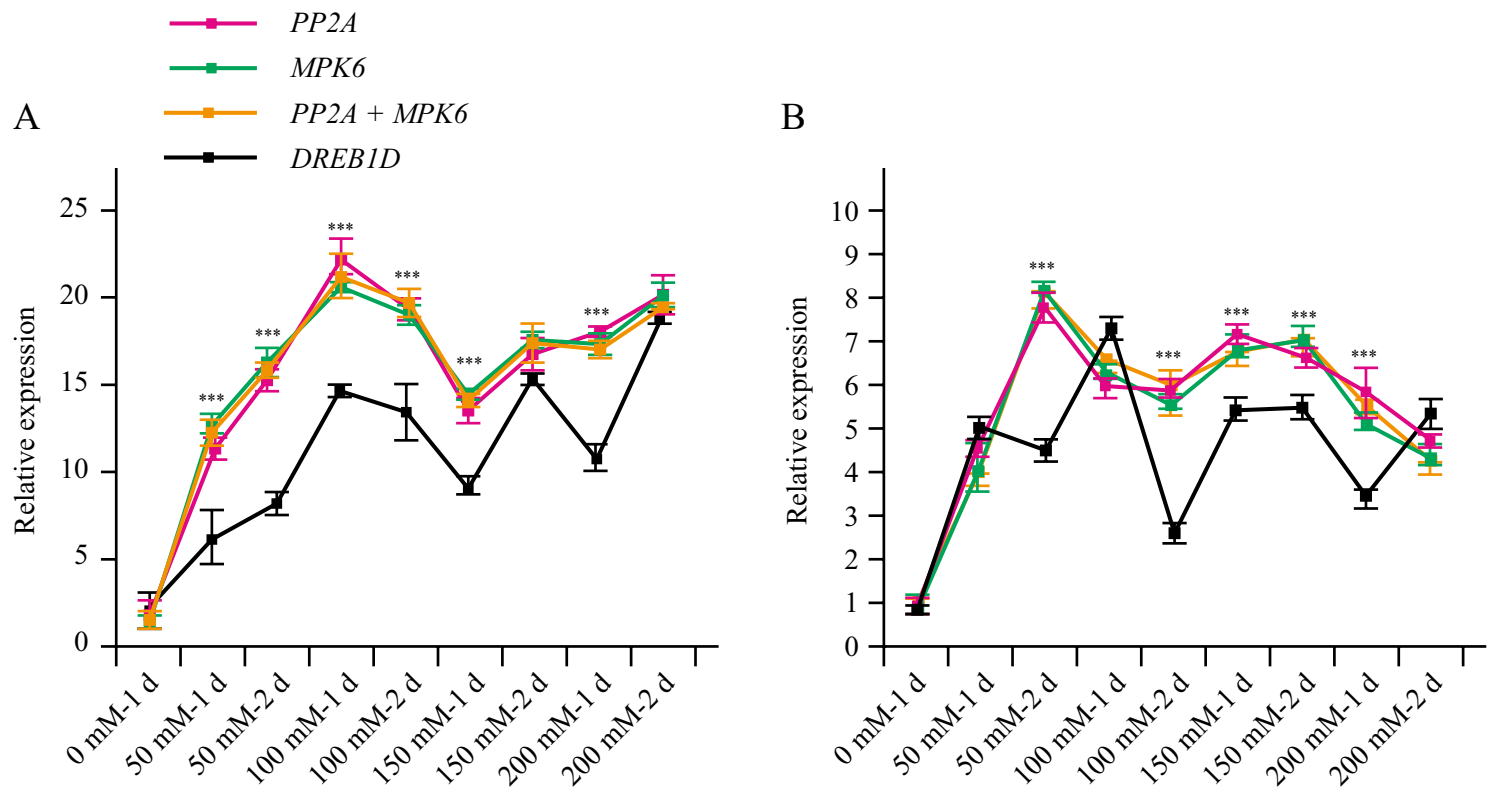

Figure 5. Relative expression levels of $M Y B(\mathbf{A})$, and $A P 2(\mathbf{B})$, normalized by different candidate reference genes, including the most or the least stable reference genes. The asterisks indicate significant differences from DREB1D using Student's $t$ test $(\mathrm{P}<0.01)$.

them under various experimental conditions ${ }^{55}$, which showed that commonly used reference genes exhibited universality in different plants. However, every gene chosen in this method must be verified before it can be used in a new plant. A universally applicable reference gene does not exist ${ }^{45,56}$.

Many previous studies reported that a single reference gene was not adequate for normalization. The expression results would generate 3-6.4-fold error using only one internal reference gene ${ }^{21}$. To obtain accurate results, two or more stable reference genes are considered as necessary ${ }^{26,57}$. The geNorm program was used to determine the optimal number of internal reference genes for normalization with the pairwise variation parameters ${ }^{21}$. The result of pairwise variation analysis of all samples in this study revealed that the V2/3 value was below the threshold of $0.15^{21}$. Therefore, the combination of the most stable two internal reference genes would guarantee an accurate result. Transcription factors $M Y B^{40}$ and $A P 2^{41}$ are involved in the salt stress response. A previous study reported that the most responsive transcription factor families were AP2/ERF and MYB of Lotus japonicus treated with $\mathrm{NaCl}^{58}$. Hence, these salt-response genes were used to validate the suitability of the candidate reference genes in germinating seeds exposed to different $\mathrm{NaCl}$ concentrations. As shown in Fig. 5, both MYB and $A P 2$ were upregulated in all seed samples treated with $\mathrm{NaCl}$ when a single or a combination of reference genes (PP2A and TUA5) was used. The results are consistent with the findings that MYB and AP2 are induced by salt stress. However, compared to using a single reference gene, the expression profiles of $A P 2$ and $M Y B$ were more accurate when a combination of reference genes (PP2A and TUA5) was used to normalize the expression (Fig. 5). Overall, our results revealed the most relevant reference genes for normalization of relative gene expression of S. glauca tissues and response to salinity stresses.

\section{Methods}

Plant material and salinity stress treatments. Suaeda glauca seeds were collected from a saline field in Dongying City, Shandong Province, China. All experimental procedures including investigation and collection were in accordance with local and national regulations. The voucher specimen of $S$. glauca has been deposited in Naturalis Biodiversity Center (herbarium ID L.1678537_544178685). Professor Jie Song (College of Life Science, Shandong Normal University, China) undertook the formal identification of S.glauca used in your study. We were allowed to collect the plant by the local government. Seeds of S.glauca were grown in a greenhouse with a temperature range of $25^{\circ} \mathrm{C} \pm 1{ }^{\circ} \mathrm{C}$ and $16-/ 8$ - $\mathrm{h}$ light/dark photoperiod cycles. The plants were grown in vermiculite and watered using $1 / 10$ Murashige and Skoog (MS) liquid medium. Considering that $S$. glauca is autochthonous of saline landscapes and that the salt content and types of salts present in nature may differ from those of artificial setup, three groups of experiments were designed for tissue collection. A total of 60 four-week-old seedlings were sorted into three groups of 20 plants. One group was irrigated with 1/10 MS liquid medium, whereas the other two were irrigated with either 100 or $300 \mathrm{mM} \mathrm{NaCl}$ dissolved in 1/10 MS liquid medium. For each group, the following samples (roots, stems, leaves, and shoots) collected at different growth stages (seedlings, adult plants, and senescent plants), and followers were used for expression analyses of candidate reference genes screening. Samples for each tissue were collected from at least five individual plants and quickly frozen in liquid nitrogen and stored at $-80^{\circ} \mathrm{C}$ throughout the sampling period. A series of $\mathrm{NaCl}$ solutions $(0,50,100,150$, and $200 \mathrm{mM} \mathrm{NaCl}$ dissolved in $1 / 10 \mathrm{MS}$ liquid medium) was used to treat the germinating seeds. Seed samples were collected at 1, 2, and 4 days after treatment. Furthermore, two-week-old seedlings were irrigated with a series of $\mathrm{NaCl}$ solutions $(0,50,100,150$, and 200 , and $400 \mathrm{mM} \mathrm{NaCl}$ dissolved in 
1/10 MS liquid medium). The total plant samples were collected at 2, 4, and 8 days after treatment. All samples were stored at $-80^{\circ} \mathrm{C}$ until further analysis.

Total RNA extraction and cDNA synthesis. Total RNA was extracted from all samples using a MiniBEST Plant RNA Extraction Kit (code no. 9769; Takara, Shiga, Japan) according to the manufacturer's instructions. As part of the extraction protocol, potential DNA contamination was digested with DNase I. The integrity of RNA was assessed by $1.2 \%$ agarose gel electrophoresis. Two complete and clearly defined RNA bands (28S and 18S) indicated that the extraction was successful. A NanoDrop 2000 Spectrophotometer (Thermo Fisher Scientific, Waltham, MA, USA) was used to determine RNA concentration and purity. The absorbance ratios at $260 / 280$ and $260 / 230 \mathrm{~nm}$ of the RNA samples ranged from 1.8 to 2.0 and 2.0 to 2.4 , respectively, indicating a suitable quality for subsequent analysis. According to the kit instructions [HiScript Q RT SuperMix for qPCR (+gDNA wiper) Kit; Vazyme, Nanjing, China], $1 \mu \mathrm{g}$ purified RNA extracted from each sample was reversetranscribed into first-strand cDNA. Next, $20 \mu \mathrm{L}$ cDNA products were diluted to a volume of $200 \mu \mathrm{L}$ for qPCR. A mixture of an equal volume from a cDNA pool of all samples was used as the template to amplify the candidate S. glauca reference genes to examine the specificity and efficiency of our qPCR primer pairs.

Candidate reference gene selection and primer design. Reference genes should be unaffected by experimental conditions and constitutively expressed, indicating their relatively stability ${ }^{17}$. However, reported reference genes are not commonly used in all plants, particularly under plant stress conditions ${ }^{30,31}$. Hence, based on several published studies ${ }^{23,25-28,32,33,35}, A C T 7, A C T 11, C C D 1, T U A 5, U P L 1, U B C 28, E F 1 \alpha, P P 2 A, D R E B 1 D$, $T I M, V-H^{+}$-ATPase, MPK6, and PHT4;5, which have been frequently reported. were selected as candidate reference genes in S. glauca. The coding sequences of these genes were obtained from GenBank according to an earlier transcriptome sequencing study ${ }^{2}$ and are listed in Supplementary File S1. The qPCR primers were designed with Primer 3 software. The length and Tm value of the primers for qPCR were identified with the OligoCalc tool $^{36}$. Before qPCR, the PCR products of all primer pairs were electrophoresed on a $2 \%$ agarose gel stained with ethidium bromide to verify successful amplification and primer specificity. Primer specificity was validated via melting curve analyses following amplification using qPCR.

qPCR conditions and amplification efficiency test. The 7500 Real-Time PCR system (Applied Biosystems, Foster City, CA, USA) was used to perform qPCR under the following conditions: $50^{\circ} \mathrm{C}$ for $2 \mathrm{~min}$ and initial denaturation at $95^{\circ} \mathrm{C}$ for $5 \mathrm{~min}$, followed by 40 cycles at $95^{\circ} \mathrm{C}$ for $10 \mathrm{~s}$ and $60^{\circ} \mathrm{C}$ for $35 \mathrm{~s}$. The dissociation curve was analyzed to determine the specificity of primer amplification, with the dissociation temperature ranging from 60 to $95^{\circ} \mathrm{C}$, by increasing the temperature stepwise by $1^{\circ} \mathrm{C} / \mathrm{min}^{26}$. The volume of the qPCR system was $20 \mu \mathrm{L}$. The reaction mixture consisted of $10 \mu \mathrm{L} 2 \times$ SYBR green mix (Q321, Vazyme), $0.4 \mu \mathrm{L}$ ROX Reference Dye, $1 \mu \mathrm{L} \mathrm{cDNA}$, and $0.4 \mu \mathrm{L}$ of each forward and reverse primer $(10 \mathrm{mM})$. Each sample was evaluated with three biological replicates. To identify the specific PCR amplification efficiency of the reference gene primer pairs, a tenfold dilution series (10-1000-fold dilution) of a cDNA isovolumetric mixing pool was used as templates for qPCR. The primer amplification efficiency $(E)$ and correlation coefficient $\left(\mathrm{R}^{2}\right)$ were calculated from the raw Cq values using the equation: $\mathrm{E}=10^{-1 / \text { slope }}-1^{28}$, where the slope is derived from the regression equation, calculated using Excel linear regression parameter (Microsoft Corp., Redmond, WA, USA).

Stability assessment of candidate genes. The statistical algorithm software programs geNorm ${ }^{21}$, NormFinder $^{22}$, BestKeeper ${ }^{37}$, and RefFinder ${ }^{38}$ were used to analyze the expression stability of candidate reference genes.

The raw Cq value was used as input data for further analysis with RefFinder and BestKeeper. $2^{-\Delta \mathrm{Cq}}$ value and $2^{\mathrm{Cq}}$ value were used as input data for further analysis with geNorm and NormFinder, respectively. The parameters calculated using geNorm were the average gene expression stability measure $(\mathrm{M})$ and average pairwise variation $(\mathrm{V})$. A lower $\mathrm{M}$ value of the reference gene indicated more stable expression ${ }^{21}$. The parameter calculated by NormFinder was the stability value, which is related to the systematic error of each candidate gene. Smaller values indicate more stable gene expression ${ }^{22}$. The parameters calculated using BestKeeper were the SD values of $\mathrm{Cq}$ and coefficient of correlation $(r)$ value. A gene with an SD value below 1.0 and $r$ value close to one indicate more stable gene expression ${ }^{37}$. RefFinder generated a final comprehensive ranking of the most consistent and appropriate candidate reference genes according to the weighted geometric mean of the results of geNorm, NormFinder, and BestKeeper ${ }^{38,39}$. The lowest geometric mean indicated the most stable gene.

Validation of reference genes. To validate the reliability of the selected reference genes, the relative expression levels of two transcription factors $M Y B^{40}$ and $A P 2^{41}$, which are involved in the salt stress response, were used as stress indicator genes to validate the suitability of candidate reference genes using qPCR at germinating seed samples.

\section{Conclusion}

We systematically evaluated the expression stability of different potential reference genes for qPCR in S. glauca. Thirteen typical reference genes were selected to identify the most stable reference genes for qPCR normalization in S. glauca. Based on the primer specificity results derived from the PCR results, UBC28, TIM, and EF1 $\alpha$ were discarded because multiple bands were amplified from the cDNA and gDNA templates. ACT7, ACT11, CCD1, TUA5, UPL1, PP2A, DREB1D, V-H $H^{+}$-ATPase, MPK6, and PHT4;5 were further analyzed in different tissues and under various salt concentration treatments. PP2A and TUA5 were identified as the best reference 
genes, according to calculations performed using the $\triangle \mathrm{Cq}$, geNorm, NormFinder, BestKeeper, and RefFinder programs. The reference genes were validated to profile the expression of $M Y B$ and $A P 2$ in germinating seeds exposed to $\mathrm{NaCl}$. The present study identified appropriate reference genes for normalization of reliable qPCR data in different $S$. glauca tissues and under salinity stress, which can guide the determination of expression profiles of target genes in S. glauca plant and related species.

Received: 28 June 2020; Accepted: 30 March 2021

Published online: 21 April 2021

\section{References}

1. Yang, C., Shi, D. \& Wang, D. Comparative effects of salt and alkali stresses on growth, osmotic adjustment and ionic balance of an alkali-resistant halophyte Suaeda glauca (Bge.). Plant Growth Regul. 56, 179-190 (2008).

2. Jin, H., Dong, D., Yang, Q. \& Zhu, D. Salt-responsive transcriptome profiling of Suaeda glauca via RNA sequencing. PLoS ONE 11, e0150504 (2016).

3. Zhao, K. et al. Two $\mathrm{Na}^{+}$and $\mathrm{Cl}^{-}$hyperaccumulators of the chenopodiaceae. J. Integr. Plant Biol. Formerly Acta Bot. Sin. 47, 311-318 (2005).

4. Kong, Y. \& Zheng, Y. Variation of sodium uptake rate in Suaeda glauca and its relation to plant size and salt acclimation. Can. J. Plant Sci. 97, 466-472 (2016).

5. Xu, Z. et al. Physiological responses of Suaeda glauca and Arabidopsis thaliana in phytoremediation of heavy metals. J. Environ. Manage. 223, 132-139 (2018).

6. Zhao, K., Fan, H. \& I.A., U. Survey of halophyte species in China. Plant Sci. 163, 491-498 (2002).

7. An, R., Sohn, D., Jeong, G. \& Kim, Y. In vitro hepatoprotective compounds from Suaeda glauca. Arch. Pharm. Res. 31, 594-597 (2008).

8. Sakagami, H. \& Satoh, K. Prooxidant action of two antioxidants: ascorbic acid and gallic acid. Anticancer Res. 17, 221-224 (1997).

9. Anand, K. et al. 3,4,5-Trihydroxy benzoic acid (gallic acid), the hepatoprotective principle in the fruits of Terminalia belericabioassay guided activity. Pharmacol. Res. 36, 315-321 (1997).

10. Xinhong, W., Chen, C. \& Xuemei, L. Optimal extraction of gallic acid from Suaeda glauca Bge. leaves and enhanced efficiency by ionic liquids. Int. J. Chem. Eng. 2016, 1-9 (2016).

11. Ashraf, M. \& Orooj, A. Salt stress effects on growth, ion accumulation and seed oil concentration in an arid zone traditional medicinal plant ajwain (Trachyspermum ammi [L.] Sprague). J. Arid Environ. 64, 209-220 (2006).

12. Shao, Y. et al. Effect of salt treatment on growth, isoenzymes and metabolites of Andrographis paniculata (Burm. f.) Nees. Acta Physiologiae Plantarum 37, (2015).

13. Lau, W. \& Sattely, E. S. Six enzymes from mayapple that complete the biosynthetic pathway to the etoposide aglycone. Science 349, 1224-1228 (2015).

14. Olofsson, L., Engström, A., Lundgren, A. \& Brodelius, P. E. Relative expression of genes of terpene metabolism in different tissues of Artemisia annua L. BMC Plant Biol. 11, 45 (2011).

15. Huapeng, S. et al. Evaluation of reference genes for normalizing RT-qPCR in leaves and suspension cells of Cephalotaxus hainanensis under various stimuli. Plant Methods 15, 31 (2019).

16. Artico, S. et al. Identification and evaluation of new reference genes in Gossypium hirsutum for accurate normalization of real-time quantitative RT-PCR data. BMC Plant Biol. 10, 49 (2010).

17. Bustin, S. A. Quantification of mRNA using real-time reverse transcription PCR (RT-PCR): trends and problems. J. Mol. Endocrinol 29, 23-39 (2002).

18. Derveaux, S., Vandesompele, J. \& Hellemans, J. How to do successful gene expression analysis using real-time PCR. Methods 50, 227-230 (2010).

19. Nicot, N., Hausman, J. F., Hoffmann, L. \& Evers, D. Housekeeping gene selection for real-time RT-PCR normalization in potato during biotic and abiotic stress. J. Exp. Bot. 56, 2907-2914 (2005).

20. Radoni, A. et al. Guideline to reference gene selection for quantitative real-time PCR. Biochem. Biophys. Res. Co 313, 856-862 (2003).

21. Vandesompele, J. et al. Accurate normalization of real-time quantitative RT-PCR data by geometric averaging of multiple internal control genes. Genome Biol 3, 0034.I-0034.II, (2002).

22. Andersen, C. L., Jensen, J. L. \& Ørntoft, T. F. Normalization of real-time quantitative reverse transcription-PCR data: A model-based variance estimation approach to identify genes suited for normalization, applied to bladder and colon cancer data sets. Cancer Res. 64, 5245-5250 (2004).

23. Xiao, X. et al. Validation of suitable reference genes for gene expression analysis in the halophyte Salicornia europaea by real-time quantitative PCR. Front Plant. Sci. 5, 788 (2014).

24. Cao, J., Wang, L. \& Lan, H. Validation of reference genes for quantitative RT-PCR normalization in Suaeda aralocaspica, an annual halophyte with heteromorphism and C4 pathway without Kranz anatomy. PeerJ 4, el697 (2016).

25. Maroufi, A. Selection of reference genes for real-time quantitative PCR analysis of gene expression in Glycyrrhiza glabra under drought stress. Biol. Plant. 60, 645-654 (2016).

26. $\mathrm{Xu}, \mathrm{Z}$. et al. Identification and validation of stable reference genes for gene expression analysis in sword-leaf dogbane using quantitative reverse transcriptase polymerase chain reaction. J. Am. Soc. Hortic. Sci. 143, 508-517 (2018).

27. Ferradas, Y. et al. Identification and validation of reference genes for accurate normalization of real-time quantitative PCR data in kiwifruit. Plant Physiol. Biochem. 102, 27-36 (2016).

28. Kong, Q. et al. Identification of suitable reference genes for gene expression normalization in qRT-PCR analysis in watermelon. PLoS ONE 9, e90612 (2014).

29. Chi, X. et al. Validation of reference genes for gene expression studies in peanut by quantitative real-time RT-PCR. Mol. Genet. Genomics 287, 167-176 (2012).

30. Hruz, T. et al. RefGenes: identification of reliable and condition specific reference genes for RT-qPCR data normalization. BMC Genomics 12, 156 (2011).

31. Marouf, A., Bockstaele, E. V. \& Loose, M. D. Validation of reference genes for gene expression analysis in chicory (Cichorium intybus) using quantitative real-time PCR. BMC Mol. Biol. 11, 15 (2010).

32. Yang, T. et al. Identification of candidate reference genes for qRT-PCR normalization studies of salinity stress and injury in Onchidium reevesii. PeerJ 7, e6834 (2019).

33. Niu, X. et al. Reference genes selection for transcript normalization in kenaf (Hibiscus cannabinus L.) under salinity and drought stress. PeerJ 3, e1347 (2015).

34. Liu, M. et al. Validation of reference genes aiming accurate normalization of qRT-PCR data in Dendrocalamus latiflorus Munro. PLoS ONE 9, e87417 (2014). 
35. Liang, W. et al. Selection and evaluation of reference genes for qRT-PCR analysis in Euscaphis konishii Hayata based on transcriptome data. Plant Methods 14, 42 (2018).

36. Kibbe, W. A. OligoCalc: an online oligonucleotide properties calculator. Nucleic Acids Res. 35, W43-W46 (2007).

37. Pfaffl, M. W., Tichopad, A., Prgomet, C. \& Neuvians, T. P. Determination of stable housekeeping genes, differentially regulated target genes and sample integrity: BestKeeper-Excel based tool using pair-wise correlations. Biotechnol. Lett. 26, 509-515 (2004).

38. Xie, F. et al. miRDeepFinder: a miRNA analysis tool for deep sequencing of plant small RNAs. Plant Mol. Biol. 80, 75-84 (2012).

39. the case of leaf-cutting Atta Sexdens. Livramento, K.G.d. et al. Gene expression profile analysis is directly affected by the selected reference gene. Insects 9, 1-16 (2018)

40. Li, C., Ng, C. K. Y. \& Fan, L. MYB transcription factors, active players in abiotic stress signaling. Environ. Exp. Bot. 114, 80-91 (2015).

41. Sun, Z. et al. Genome-wide analysis of AP2/ERF family genes from Lotus corniculatus shows LcERF054 enhances salt tolerance. Funct. Integr. Genomics 14, 453-466 (2014).

42. Bustin, S. A. Quantification of mRNA using real-time reverse transcription PCR (RT-PCR): Trends and problems. J. Mol. Endocrinol. 29, 23-39 (2002).

43. Huggett, J., Dheda, K., Bustin, S. \& Zumla, A. Real-time RT-PCR normalisation; strategies and considerations. Genes Immun. 6, 279-284 (2005).

44. Yeap, W., Loo, J. M., Wong, Y. C. \& Kulaveerasingam, H. Evaluation of suitable reference genes for qRT-PCR gene expression normalization in reproductive, vegetative tissues and during fruit development in oil palm. Plant Cell Tissue Organ. Cult. 116, 55-66 (2014).

45. Gutierrez, L. et al. The lack of a systematic validation of reference genes: A serious pitfall undervalued in reverse transcriptionpolymerase chain reaction (RT-PCR) analysis in plants. Plant Biotechnol. J. 6, 609-618 (2008).

46. Hong, Y. \& Dai, S. Selection of reference genes for real-time quantitative polymerase chain reaction analysis of light-dependent anthocyanin biosynthesis in Chrysanthemum. J. Amer. Soc. Hort. Sci. 140, 68-77 (2015).

47. Guo, S. et al. Transcriptome sequencing revealed molecular mechanisms underlying tolerance of Suaeda salsa to saline stress. PLoS ONE 14, e0219979 (2019).

48. Suzuki, T., Higgins, P. J. \& Crawford, D. R. Control selection for RNA quantitation. Biotechniques 29, 332-337 (2000).

49. Kumar, V. et al. Traditional and novel references towards systematic normalization of qRT-PCR data in plants. Aust. J. Crop Sci. 5, 1455-1468 (2011)

50. Galeano, E. et al. Identification and validation of quantitative real-time reverse transcription PCR reference genes for gene expression analysis in teak (Tectona grandis L.f.). BMC Res. Notes 7, 464, (2014).

51. Auler, P. A. et al. Evaluation of stability and validation of reference genes for RT-qPCR expression studies in rice plants under water deficit. J Appl Genet 58, 163-177 (2017).

52. Li, C. et al. Validation of reference genes for gene expression studies in tartary buckwheat (Fagopyrum tataricum Gaertn.) using quantitative real-time PCR. PeerJ 7, e6522 (2019).

53. Ji, N., Li, L., Lin, L. \& Lin, S. Screening for suitable reference genes for quantitative real-time PCR in Heterosigma akashiwo (Raphidophyceae). PLoS ONE 10, e0132183 (2015).

54. Moura, J.C.M.S. et al. Validation of reference genes from Eucalyptus spp. under different stress conditions. BMC Res. Notes 5, 634, (2012).

55. Mu, H. et al. Identification and validation of reference genes for gene expression studies in sweet osmanthus (Osmanthus fragrans) based on transcriptomic sequence data. J. Genet. 96, 273-281 (2017).

56. Chandna, R., Augustine, R. \& Bisht, N. C. Evaluation of candidate reference genes for gene expression normalization in Brassica juncea using real time quantitative RT-PCR. PLoS ONE 7, 153 (2012).

57. Niaz, Z. et al. Identification of valid reference genes for the normalization of RT-qPCR gene expression data in Alexandrium catenella under different nutritional conditions. J. Appl. Phycol. 31, 1819-1833 (2018).

58. Sanchez, D. H. et al. Integrative functional genomics of salt acclimatization in the model legume Lotus japonicus. Plant J. 53, 973-987 (2008).

\section{Acknowledgements}

We thank Professor Jie Song (College of Life Science, Shandong Normal University, China) for providing the S. glauca seeds.

\section{Author contributions}

Conceptualization, Z.X.; data curation, T.R. and H.D.; writing-original draft preparation, Z.X. and M.W.; writingreview and editing, M.W. and P.M.; funding acquisition, Z.X. All authors have read and agreed to the published version of the manuscript.

\section{Funding}

This work was supported by the National Natural Science Foundation of China (31900276), and the Doctor Foundation of Shandong (ZR2019BC073). The funders had no role in study design, data collection and analysis, decision to publish, or preparation of the manuscript.

\section{Competing interests}

The authors declare no competing interests.

\section{Additional information}

Supplementary Information The online version contains supplementary material available at https://doi.org/ 10.1038/s41598-021-88151-5.

Correspondence and requests for materials should be addressed to Z.X.

Reprints and permissions information is available at www.nature.com/reprints.

Publisher's note Springer Nature remains neutral with regard to jurisdictional claims in published maps and institutional affiliations. 
(c) (i) Open Access This article is licensed under a Creative Commons Attribution 4.0 International cc) License, which permits use, sharing, adaptation, distribution and reproduction in any medium or format, as long as you give appropriate credit to the original author(s) and the source, provide a link to the Creative Commons licence, and indicate if changes were made. The images or other third party material in this article are included in the article's Creative Commons licence, unless indicated otherwise in a credit line to the material. If material is not included in the article's Creative Commons licence and your intended use is not permitted by statutory regulation or exceeds the permitted use, you will need to obtain permission directly from the copyright holder. To view a copy of this licence, visit http://creativecommons.org/licenses/by/4.0/.

(C) The Author(s) 2021 